\title{
The Biodiesel Economic Indicators in Northern Brazil Based on Tocantins State
}

\author{
Fernando Silva Lima ${ }^{1}$, Waldecy Rodrigues ${ }^{2} \&$ Nilton Marques de Oliveira ${ }^{3}$ \\ ${ }^{1}$ Department of Regional Development, Federal University of Tocantins, Federal Institute of Education, Science and \\ Technology of Maranhão, Rua Imperatriz, Carolina, Brazil \\ ${ }^{2}$ Department of Comparative Studies, Federal University of Tocantins, Avenida NS 15, Quadra 109 Norte, North \\ Master Plan, Palmas, Brazil \\ ${ }^{3}$ Department of Regional Development and Agribusiness, Federal University of Tocantins, Avenida NS 15, Quadra \\ 109 Norte, North Master Plan, Palmas, Brazil
}

Correspondence: Fernando Silva Lima, PhD Student in Regional Development from the Federal University of Tocantins (UFT) and Professor at the Federal Institute of Education, Science and Technology of Maranhão (IFMA) Carolina Advanced Campus, Rua Imperatriz, City of Carolina, Maranhão State, Brazil.

Received: January 21, 2020

Accepted: March 11, 2020

Online Published: March 24, 2020

doi:10.5430/ijba.v11n2p17

URL: https://doi.org/10.5430/ijba.v11n2p17

\begin{abstract}
Abstratct
This article aimed to perform a regional analysis of biofuel through the biodiesel production capacity in Tocantins in 2008 and 2017. The guiding question of this research was: what is the importance of the biodiesel sector in Brazil and Tocantins, in relation to the sectors of services, industry and storage services in terms of production capacity. The hypothesis is that, in relation to production capacity, the Tocantins biodiesel sector has lost its potential compared to other economic sectors in the state. Taking as theoretical assumption the theories of regional development. Data were collected from the website of the Brazilian Institute of Geography and Statistics (IBGE) and the National Petroleum Agency (ANP). The results show that biodiesel in 2008 had potential for Tocantins economy, but not in the same proportionality in 2017.
\end{abstract}

Keywords: Brazil, biofuel, economic indicators, Tocantins

\section{Introduction}

The regional analysis study in Tocantins, focused on the biodiesel sector, is based on the assumption that, given Brazil's economic situation, it is necessary to investigate the location, potentiality and structure in various regions, especially in Tocantins, the Brazilian state where a One of the local challenges may be the economic balance of the sectors.

Therefore, studies on the location of economic activities are of great importance to regional planners (local and state authorities), as they are, as a rule, responsible for the balanced division of space. In addition, entrepreneurs are interested in localization issues, as localization options have a major impact on production costs and the current and future competitiveness of companies (Benko, 1999).

This study becomes even more interesting when we know the emergence of the policy that integrates the biodiesel sector, called national biofuels policy to minimize the climate problems of the country and the world and thus contribute to the environment by reducing greenhouse gas emissions.

Biodiesel is integrated with biofuel as it is understood as a type of fuel of biological or natural origin. It is a renewable source of energy used to burn biomass or its derivatives, such as ethanol (fuel ethanol), biodiesel, biogas, vegetable oil, among others (Azevedo and Lima 2016).

Therefore, it is believed that the biofuels sector is able to contribute to sustainable development, as this activity can generate energy savings that, according to Leite and Leal (2007), is an alternative to reduce greenhouse gases that will have to be used, but will face difficulties in some cases by requiring changes in habits, such as the use of the private vehicle for transportation, so that global warming in the coming years does not endanger new generations.

In this context, it is clear that Brazil's national biofuels policy is not only of interest to the country, but to the world, 
because the effect of global warming has demanded from world leaders a change in the behavior of society, which depends on the alternatives that are being adopted by countries and their characteristics that include the availability of natural resources, financial capacity, infrastructure and technology installation, among others (Farina and Rodrigues, 2018).

Although Brazil is always living in times of financial hardship, it is noteworthy that the country is a pioneer in the use of renewable sources and has a unique position in the world, with several options to increase the production and use of clean energy, around $40 \%$ of The national matrix is made up of renewable sources, with bioenergy accounting for approximately $18 \%$ of the total. Specifically in the transport sector, biofuels also replace $10 \%$ of diesel needs and about $40 \%$ of gasoline consumption. These figures were obtained without prejudice to the rational use of natural resources or food production in the country. In the case of sugarcane, for example, we use only $0.6 \%$ of the national territory to grow this grass for biofuel production. The consolidation of the Brazilian position and the materialization of the potential associated with biofuels, in turn, require a long-term guideline capable of directing and attracting investments in national production (Farina, Rodrigues, 2018).

Based on the above, the question is: what is the importance of the biodiesel sector in Brazil, in Tocantins, in relation to services, industry and storage services in Tocantins, in terms of production capacity? The hypothesis is that, referring to production capacity, the Tocantins biodiesel sector lost its potential in relation to the other economic sectors of the state between 2008 and 2017.

Thus, the overall objective is to conduct a regional biofuel analysis through the production capacity of the biodiesel activity in Tocantins in 2008 and 2017.

That said, this paper is divided into four parts. In addition to this introduction, the following presents the theory of regional development; then the methodological procedures; in the third, the discussion about the results achieved and, finally, the final considerations.

\section{The Theory of Regional Development}

It is understood that before analyzing the collected data, obviously, a theoretical survey is needed to understand the puzzle of the Tocantins biodiesel industry from Douglas North's theory of location.

Although this article focuses on a very narrow subject, such as biodiesel, it is intended to counteract location theory, as Douglas North makes an in-depth analysis of the development of North American regions so that a broad understanding can be gained of the biodiesel industry in the state of Tocantins.

But what does a theory of localization say? North (1955) argues that a specific region goes through different stages during the development process, begins with subsistence activities, diversifying agricultural production through interconnected trade with other regions, achieving industrialization and finally achieving specialization in third party activities, mainly producing for foreign market.

In this theory, the author presents, based on North American regions, evidence that the different procedural stages of development were not actually observed by social actors.

To this end, North (1955) describes the United States colonization model as a capitalist enterprise, because the growth of these regions is determined by the world market, whose basic objective was to exploit land and its resources to produce goods that could be traded in the world abroad and that would turn into monetary income.

Evidently North (1955) starts from the premise, showing that the development of the mentioned region is essentially due to its capacity to produce two exportable products, wheat and wood, without observing the subsistence stage. Activities, as advocated by the theory of regional growth. Importantly, the American regions analyzed developed the capacity to produce only one or two exportable products, diversifying their base only after reducing transportation costs.

There is a conception that the author, when addressing the issue of development, is using the economic base theory, considering that in this theory Piffer (2009) states that the growth of a region is due to the increase of economic base activities and, consequently, the demand for products it offers outside the region. As basic activities grow and expand, the entire regional economy grows.

The economic base theory explains these interregional relations that involve the flow of goods, people, and services, and assesses the implications of these flows between the region and the rest of the world economy (RICHARDSON, 1975).

Based on this theory, Schwartzman (1975) understands that the development of a region depends on the dynamism 
of this base and its diffusion in the rest of the regional economy, that is, it must present two necessary conditions for development: 1) maintenance of the dynamism of the product exported; 2) the spread of dynamism to other sectors of the economy.

\section{Methodological Procedures}

This article is based on the taxonomy of Vergara (2016) and is for descriptive, explanatory and applied purposes and as for the means of investigation is bibliographic and documentary.

Descriptive because it intends to characterize the productive capacity of the biodiesel sector in the state of Tocantins and in the North, confronting with the northern states and among the Brazilian regions. Explanatory because it aims to show the development of biodiesel production in Tocantins and in the northern region. Applied because it aims to contribute to the regional economy in Tocantins and the northern region.

It is bibliographic because it intends to use a vast literature available in books, articles, theses and even available collections on the subject. It is documentary because it intends to use the archives of the Brazilian Institute of Geography and Statistics (IBGE) and the National Petroleum Agency (ANP) that contain information about the economic activities analyzed between the states and the Brazilian regions.

It is known that Brazil is divided into 5 regions: north, northeast, southeast, south and midwest. However, this study sought to perform a regional biodiesel analysis comparing the northern region with the other Brazilian regions and comparing Tocantins among the other states in the northern region of the country.

Initially, a literature review was made on academic websites to collect up-to-date information on Brazil's national biodiesel policy.

After completing the theoretical survey, searches were conducted on the productivity capacity in cubic meters of economic sectors on the website of the Brazilian Institute of Geography and Statistics (IBGE) and the National Petroleum Agency (ANP) to collect capacity-related data. B100 biodiesel, trade, industry, storage and agricultural production sectors to understand the economic dynamics of the northern region in relation to other regions of Brazil and to understand the dynamics of the state of Tocantins in relation to other states in the northern region, such as : Acre, Amazonas, Amapá, Rondônia, Roraima Pará in the years 2008 and 2017.

It is noteworthy that the data were analyzed based on locational quotient (QL) and location coefficient (CL).

According to Alves (2012), the locational quotient (QL) shows the locational behavior of the branches of activity, as well as the most specialized (potential) sectors in the different regions, comparing them to a reference macroregion. The Locational Quotient (QL) is not only the most widespread and the most used in the analysis as it is recommended by North (1977). In this case, this study will be compared to regions with the country and states with the northern region. The QL formula consists of:

$$
\mathbf{Q} \mathbf{L}_{\mathbf{i j}}=\frac{\mathbf{E}_{\mathbf{i j}} / \sum_{\mathbf{i}} \mathbf{E}_{\mathbf{i j}}}{\sum_{\mathbf{j}} \mathbf{E}_{\mathbf{i j}} / \sum_{\mathbf{i}} \sum_{\mathbf{j}} \mathbf{E}_{\mathbf{i j}}}
$$

Where:

$\mathrm{E}_{\mathrm{ij}}=$ Production capacity in cubic meters in sector $\mathrm{i}$ of region $\mathrm{j}$;

$\sum_{\mathrm{j}} \mathrm{E}_{\mathrm{ij}}=$ Total production capacity in cubic meters in region $\mathrm{j}$;

$\sum_{\mathrm{i}} \mathrm{E}_{\mathrm{ij}}=$ Production capacity in cubic meters of sector $\mathrm{i}$ in the reference region;

$\sum_{\mathrm{i}} \sum_{\mathrm{j}} \mathrm{E}_{\mathrm{ij}}=$ Total production capacity in cubic meters in the reference region.

Thus, QL compares the percentage share of employed persons in a region $\mathrm{j}$ with the percentage share of the reference region. QL tells you how many times sector $\mathrm{i}$ is more (or less) specialized for region $\mathrm{j}$ vis-à-vis the reference macroregion. Traditionally, region $\mathrm{j}$ specialization in the macroregional context, in relation to the sector studied, is demonstrated when the QL assumes values above 1 . In such cases, the sector will be specialized. The contract will occur when the QL is less than 1 (Alves, 2012, p.40).

The " $i$ " means sectors such as biodiesel, commerce, industry, warehousing service and agricultural production. The " $\mathrm{j}$ ", when compared to the regions between them, means the regions: north, northeast, southeast, south and midwest and the "reference region" means the country. The " $\mathrm{j}$ ", when compared to the Brazilian states between them, means the states: Acre, Amazonas, Amapá, Rondônia, Roraima, Pará and Tocantins and the "reference region" means the northern region. 
According to Alves (2012, p. 41), the location coefficient (CL) is the sum for all regions of the percentage share of sector $\mathrm{i}$ in region $\mathrm{j}$ over the reference region, minus the total percentage share of region $\mathrm{j}$ over the reference region, divided by 2 . The location coefficient (CL) formula is:

$$
C L=(E j(! j e i-E j j e i !)) / 2
$$

Where:

$E j=$ Production capacity in cubic meters in sector $\mathrm{i}$ of region $\mathrm{j}$;

! jei $=$ Total production capacity in cubic meters in region $\mathrm{j}$;

Ej jei! = Production capacity in cubic meters of sector $\mathrm{i}$ in the reference region;

This coefficient ranges from 0 to 1 and allows to identify the degree of relative dispersion of economic activities and to select those that presumably would be less prone to spatial concentration. The closer to 0 , the sector will be distributed regionally similar to the set of all sectors in each region (ALVES, 2012, p. 41).

\section{Results and Discussion}

\subsection{Economic Context of Tocantins}

This topic presents the economic context of Tocantins in relation to biodiesel, as Buarque (1999) states that local development is an endogenous process of mobilization of social energies capable of promoting economic dynamism and improving the population's quality of life, based on the potential and the development of society in the process. Its sustainability is linked to increased social opportunities, the viability and competitiveness of the local economy, as well as the participation of society and the conservation of natural resources.

Gradually, this economic dynamism in Tocantins has been occurring as the federal and state governments seek to promote sector interaction, encouraging, through policies aimed at building and improving the transportation network, improving state and municipal corridors linked to the longest corridor, BR 153, telecommunications, agribusiness, among others (OLIVEIRA and PIFFER, 2018).

Figure 1 shows spatially that Tocantins is from the states of Brazil with an estimated population of 1,555,229 people for 2018, since in the last census (2010) the population was $1,383,445$ inhabitants (IBGE).

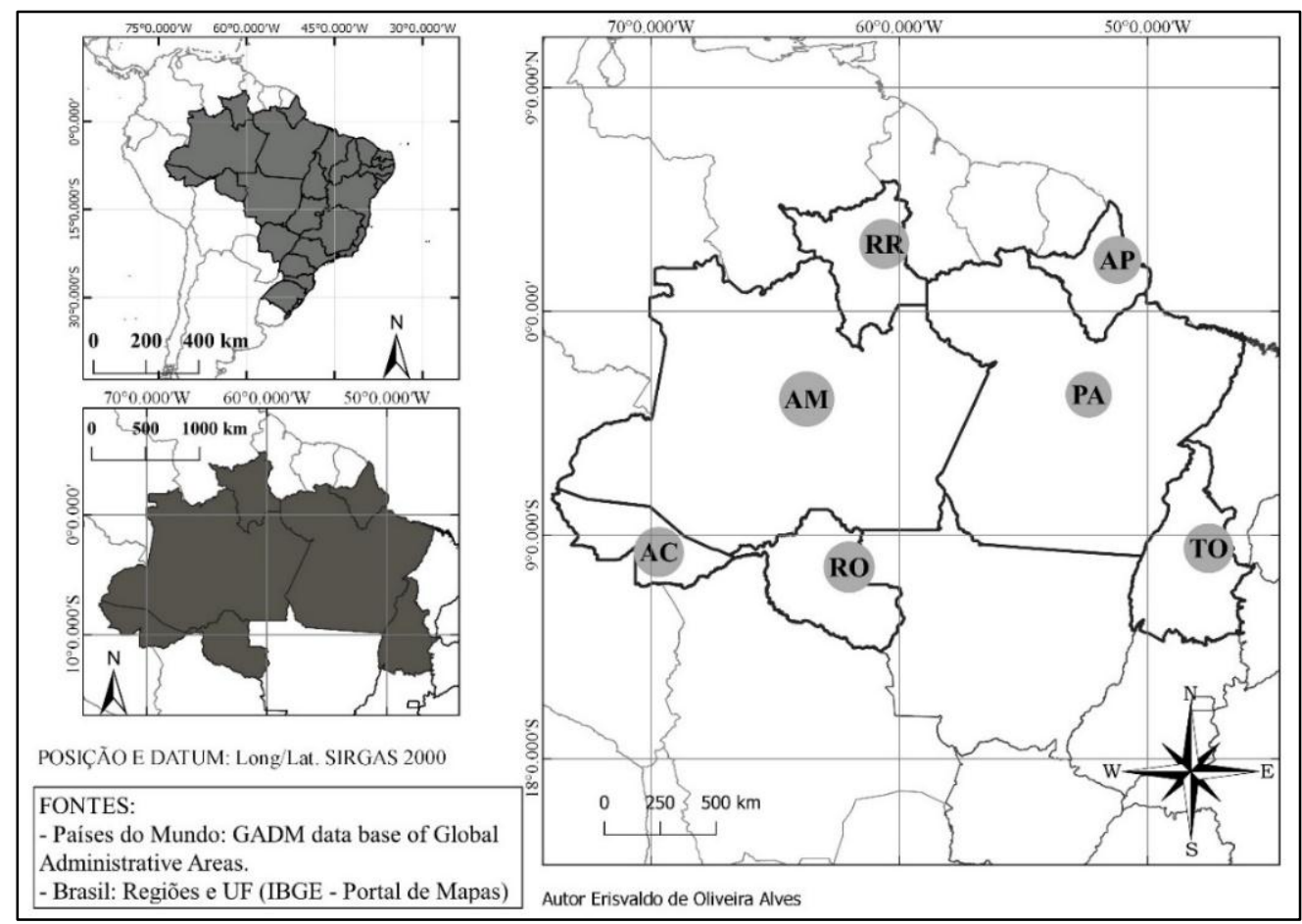

Figure 1. Spatial location of northern Brazil

Source: National Petroleum Agency - ANP (2018); Brazilian Institute of Geography and Statistics - IBGE (2018) 
Initially, looking at Figure 1, it can be noted on the map that Tocantins has an advantage in terms of spatial location compared to the states of Acre, Amapá, Rondônia, Amazonas, Roraima and Pará due to geographic centralization, which is why allow the flow of production to both the northern region and other regions of the country, from BR-153 which is one of the largest modes to enable various sectors of the economy, especially biodiesel. See Figure 1.

Although Tocantins is geographically centralized, it is evident from Figure 2 that, in 2008, the state was specialized in biodiesel production, because during this period, in Tocantins, the biodiesel sector was able to develop to the point of being considered a potential in the region, surpassing the other states of northern Brazil, but in 2017 the sector in Tocantins ceases to be specialist and becomes specialist in the state of Rondônia. This specialization is simplified and translated into its specialization / export base (ALVES, 2012). See figure 2.

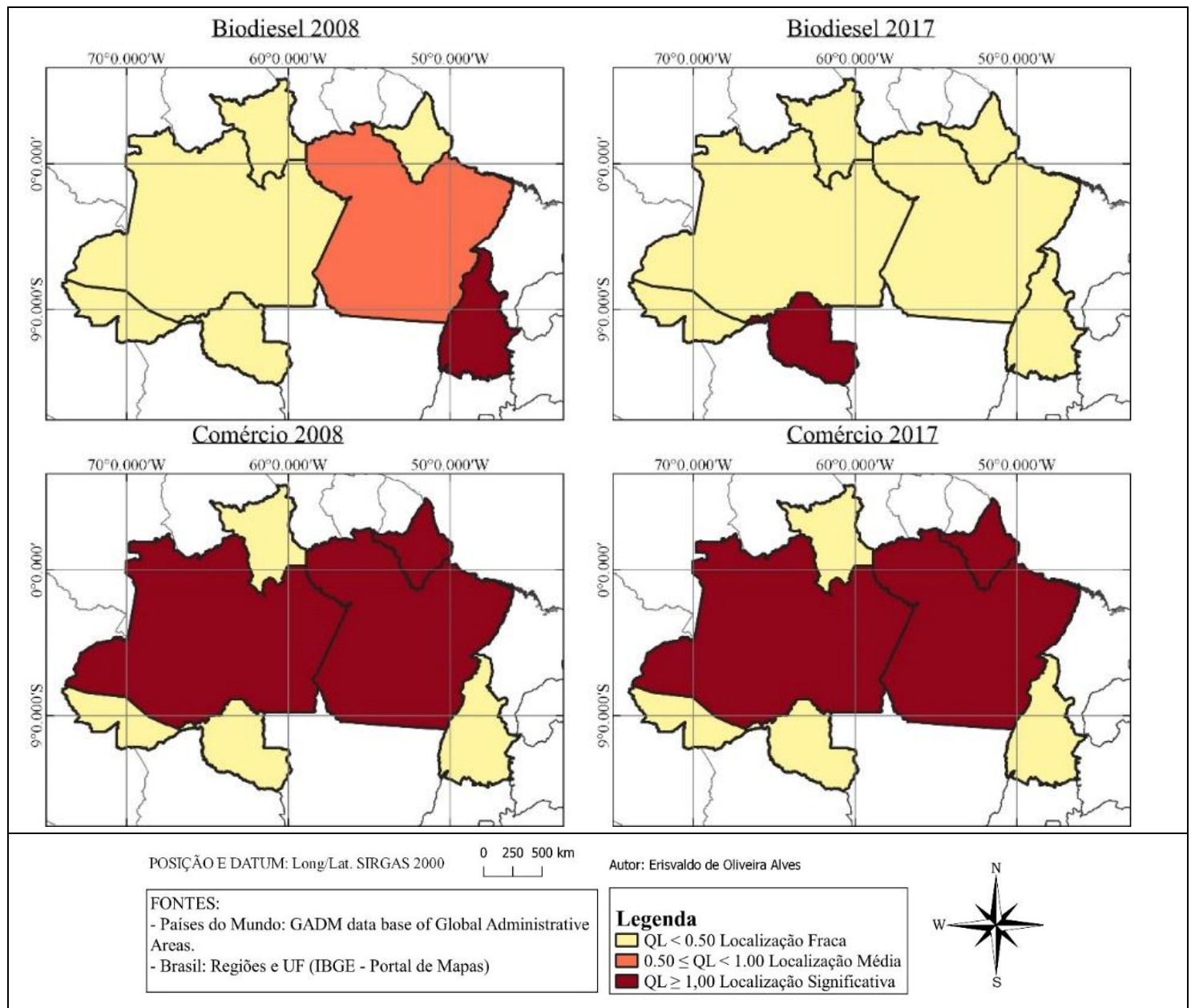

Figure 2. Spatial location by sector of the Brazilian regions for 2008 and 2017

Source: National Petroleum Agency - ANP (2018); Brazilian Institute of Geography and Statistics - IBGE (2018)

In Figure 3, in 2008, it can be seen that, at a time when the biodiesel sector was seen as a potential for Tocantins, the industrial sector was seen as low potential, although in 2017, when the biodiesel sector in the Tocantins is no longer specialized, it is observed that the industrial sector advances little in terms of specialization. See Figure 3. 

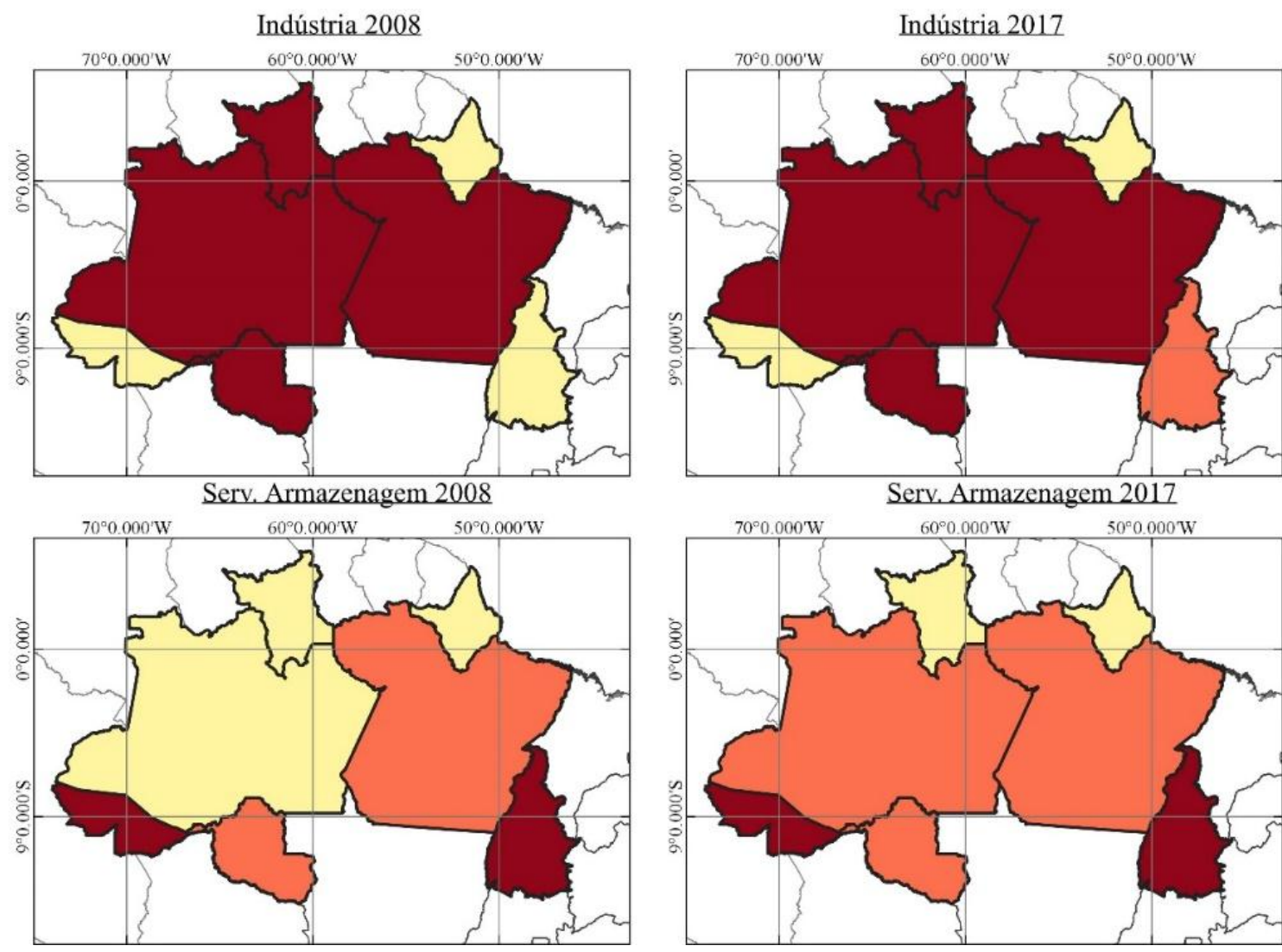

Figure 3. Spatial location by sector of the Brazilian regions for 2008 and 2017

Source: National Petroleum Agency - ANP (2018); Brazilian Institute of Geography and Statistics - IBGE (2018)

It is believed that the explanation for this small advance in terms of specialization in the industrial sector lies in the studies of thesis Oliveira (2015) that, by studying Perroux's theories, he concluded that, in Tocantins, there is no driving industry, but economic activities which add other sectors indirectly to the economy, such as the agro-industrial complex, a meat fridge located in Araguaína. This agro-industrial complex ends up spreading other demands, such as services, input sales, transportation, among others.

In the same vein, as shown in Figure 3, it is noted that while the biodiesel sector decreases the level of specialization and the industrial sector presents a slight advance, it is clear that the storage services sector in 2008 and 2017 highlights its potential economic growth in the state.

Thus, it can be said that the storage sector in Tocantins becomes powerful and that, for Paiva (2004), by identifying the potential of a region, the sectors that, once mobilized, promoted, generate the greatest benefits are also identified per unit of cost because they have the power to multiply in space and time at the time of promotion.

Table 1 shows comparatively the capacity in cubic meters of the biodiesel production sector in relation to the other sectors of the Brazilian economy in each region of the country between 2008 and 2017. Initially, it is observed that the north and southeast regions during the period analyzed, are not specialized in the production of the product. See table 1 . 
Table 1. Locational Quotient (QL) by sectors of the Brazilian regions for the years 2008 and 2017

\begin{tabular}{|c|c|c|c|c|c|c|c|c|c|c|}
\hline \multirow[t]{2}{*}{ Activity } & \multicolumn{2}{|c|}{ North } & \multicolumn{2}{|c|}{ Northeast } & \multicolumn{2}{|c|}{ Southeast } & \multicolumn{2}{|c|}{ South } & \multicolumn{2}{|c|}{ Midwest } \\
\hline & 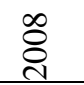 & 공 & $\stackrel{\infty}{8}$ & 홍 & 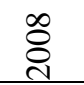 & 홍 & 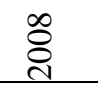 & 공 & 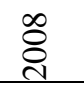 & 호 \\
\hline Biodiesel & 0,47 & 0,06 & 1,14 & 0,94 & 0,42 & 0,23 & 0,78 & 1,29 & 2,87 & 1,83 \\
\hline Trade & 0,4 & 0,36 & 0,36 & 0,33 & 0,93 & 0,93 & 1,52 & 1,6 & 0,54 & 0,59 \\
\hline Industry & 0,38 & 0,76 & 1,6 & 1,69 & 0,99 & 1,1 & 1,09 & 0,86 & 0,59 & 0,88 \\
\hline Warehousing Service & 1,95 & 1,8 & 0,65 & 0,94 & 1,19 & 1,31 & 0,69 & 0,71 & 1,24 & 0,87 \\
\hline Agriculture and Livestock & 0,55 & 0,7 & 1,01 & 1,24 & 0,2 & 0,42 & 0,79 & 0,85 & 3,44 & 1,96 \\
\hline
\end{tabular}

Source: Prepared by the author based on data from the National Petroleum Agency - ANP (2018); Brazilian Institute of Geography and Statistics - IBGE (2018). Note: QL $\geq 1=$ Specialized Sector; $0.50 \leq$ QL $\geq 0.999=$ Medium specialized sector; $\mathrm{QL} \leq 0.499=$ Non-specialized sector.

However, the Northeast region, in 2008, was considered a specialized sector, in 2017 this region came to be seen as a medium-specialty region in contrast to the southern region which, in 2008 , the sector was considered an average specialist and became a specialized region in 2017 with a QL of 1.29.

Regarding the Midwest region, it is noteworthy that in 2008 and 2017, the region is considered a specialized productive sector, since in 2008 there was a QL of 2.87 and, in 2017, a QL of 1.83.

It is observed that the Midwest region shows that biodiesel is a potential in this locality, is the most specialized among the other regions of Brazil, since the QL indicator in 2008 and 2017 was 2.87 and 1.83 respectively. However, in this range it also registered a decrease of $-36.24 \%$ in production capacity according to table 02 . See table 2.

Table 2. Variation in QUAL of the biodiesel sector in relation to other economic sectors in the regions

\begin{tabular}{llllll}
\hline Activity & North & Northeast & Southeast & South & Midwest \\
\hline Biodiesel & $-87,23 \%$ & $-17,54 \%$ & $-45,24 \%$ & $65,38 \%$ & $-36,24 \%$ \\
\hline Trade & $-10,00 \%$ & $36,00 \%$ & $0,00 \%$ & $5,26 \%$ & $9,26 \%$ \\
\hline Industry & $100,00 \%$ & $76,00 \%$ & $11,11 \%$ & $-21,10 \%$ & $49,15 \%$ \\
\hline Warehousing Service & $-7,69 \%$ & $180,00 \%$ & $10,08 \%$ & $2,90 \%$ & $-29,84 \%$ \\
\hline Prod. Agropecuária & $27,27 \%$ & $70,00 \%$ & $110,00 \%$ & $7,59 \%$ & $-43,02 \%$
\end{tabular}

Source: Prepared by the author based on data from the National Petroleum Agency - ANP (2018); Brazilian Institute of Geography and Statistics - IBGE (2018)

In the northern region, the biodiesel sector in 2008 and 2017, although not a potential in relation to the storage sector, was the most negatively impacted in this period, as the initial QL was 0.47 and the 0.06 , this shows a $-87.23 \%$ drop in production capacity in cubic meters at this location.

Finally, in this study, it is clear that the Southern region in 2017 is considered one that specializes in biodiesel production, since the 2017 QL was 1.29. It is also noteworthy that this region was the only one that did not have a negative impact on production capacity, in fact, there was a growth of $65.38 \%$, unlike the other Brazilian regions. 
Table 3. Locational Quotient (QL) by sectors in the northern states in 2008 and 2017

\begin{tabular}{|c|c|c|c|c|c|c|c|c|c|c|c|c|c|c|}
\hline \multirow[t]{2}{*}{ Activity } & \multicolumn{2}{|l|}{ RO } & \multicolumn{2}{|l|}{$\mathrm{AC}$} & \multicolumn{2}{|l|}{$\mathrm{AM}$} & \multicolumn{2}{|l|}{ RR } & \multicolumn{2}{|l|}{$\mathrm{PA}$} & \multicolumn{2}{|l|}{ AP } & \multicolumn{2}{|l|}{ TO } \\
\hline & $\stackrel{\infty}{8}$ & $\frac{\sqrt{0}}{i}$ & $\stackrel{\infty}{8}$ & $\bar{\sigma}$ & $\stackrel{\infty}{8}$ & 공 & $\stackrel{\infty}{8}$ & $\frac{\sqrt{0}}{\sigma}$ & $\stackrel{\infty}{8}$ & $\frac{\sqrt{0}}{\sigma}$ & $\stackrel{\infty}{8}$ & 홍 & $\stackrel{\infty}{8}$ & $\stackrel{ }{\circ}$ \\
\hline Biodiesel & 0.12 & 8.25 & 0 & 0 & 0 & 0 & 0 & 0 & 0.84 & 0 & 0 & 0 & 1.41 & 0.13 \\
\hline Trade & 0 & 0 & 0 & 0 & 5.97 & 3.34 & 0 & 0 & 1.92 & 1.13 & 19.92 & 12 & 0 & 0 \\
\hline Industry & 1.76 & 2.69 & 0 & 0 & 2.99 & 2.26 & 6.85 & 5.78 & 1.92 & 1.32 & 0 & 0 & 0.35 & 0.51 \\
\hline $\begin{array}{l}\text { Warehousing } \\
\text { Service }\end{array}$ & 0.98 & 0.79 & 1.32 & 1.56 & 0.35 & 0.52 & 0 & 0 & 0.54 & 0.51 & 0 & 0 & 1.24 & 1.36 \\
\hline $\begin{array}{l}\text { Agriculture } \\
\text { and Livestock }\end{array}$ & 0 & 0 & 0 & 0 & 0 & 0 & 0 & 0 & 5.09 & 3.55 & 0 & 0 & 0 & 0.4 \\
\hline
\end{tabular}

Source: Prepared by the author based on data from the National Petroleum Agency - ANP (2018); Brazilian Institute of Geography and Statistics - IBGE (2018). Caption: RO = Rondônia; $A C=$ Acre; AM = Amazonas; RR = Roraima; $\mathrm{PA}=$ Pará; $\mathrm{AP}=$ Amapá; $\mathrm{TO}=$ Tocantins

It can be observed that the biodiesel production capacity in the northern region is not potential, as in the Midwest region, however, this economic activity in Tocantins was of great relevance to the northern region in 2008, since The QL presented was 1.41, but in 2017 it did not maintain the same momentum, having a QL of 0.13.

In contrast to Tocantins, the state of Rondônia which, in 2008, was not considered a power in the northern region when the QL was 0.12 , but in 2017 became attractive and dynamic for Rondônia, because the presented QL was 825

Finally, in relation to the biodiesel sector, it is demonstrated that the states of Tocantins in 2008 and Rondônia in 2017 have traditionally been important in the regional context when the QL assumes values above 1 (ALVES, 2012).

Table 4 shows, by percentage change, the economic development of the biodiesel sector in the northern states compared to other economic activities in 2008 and 2017. See Table 4.

Table 4. Variation in QUAL of the biodiesel sector in relation to the other economic sectors in the northern states

\begin{tabular}{llllllll}
\hline Activity & $\mathrm{RO}$ & $\mathrm{AC}$ & $\mathrm{AM}$ & $\mathrm{RR}$ & $\mathrm{PA}$ & $\mathrm{AP}$ & $\mathrm{TO}$ \\
\hline Biodiesel & $6775.00 \%$ & $0.00 \%$ & $0.00 \%$ & $0.00 \%$ & $-100.00 \%$ & $0.00 \%$ & $-90.78 \%$ \\
\hline Trade & $0.00 \%$ & $0.00 \%$ & $-44.05 \%$ & $0.00 \%$ & $-41.15 \%$ & $-39.76 \%$ & $0.00 \%$ \\
\hline Industry & $52.84 \%$ & $0.00 \%$ & $-24.41 \%$ & $-15.62 \%$ & $-31.25 \%$ & $0.00 \%$ & $45.71 \%$ \\
\hline Warehousing Service & $-19.39 \%$ & $18.18 \%$ & $48.57 \%$ & $0.00 \%$ & $-5.56 \%$ & $0.00 \%$ & $9.68 \%$ \\
\hline Agriculture and Livestock & $0.00 \%$ & $0.00 \%$ & $0.00 \%$ & $0.00 \%$ & $-30.26 \%$ & $0.00 \%$ & $0.00 \%$ \\
\hline
\end{tabular}

Source: Prepared by the author based on data from the National Petroleum Agency - ANP (2018); Brazilian Institute of Geography and Statistics - IBGE (2018). Caption: RO = Rondônia; AC = Acre; AM = Amazonas; RR = Roraima; $\mathrm{PA}=$ Pará; $\mathrm{AP}=$ Amapá; $\mathrm{TO}=$ Tocantins

Given the above, it is observed that the state of Tocantins suffered a significant reduction in biodiesel production capacity of $-90.78 \%$ between 2008 and 2017, in contrast, the state of Rondônia grew 6775\%, this percentage shows how often The biodiesel sector is more important to Rondônia than to northern Brazil.

According to Table 5, it can be observed that biodiesel production capacity in Brazil is not concentrated because the CL in 2008 is 0.3073 and in 2017 it is 0.2926 , ie there is a relative dispersion with all regions of the country, which implies that there is a low spatial concentration in the biodiesel production chain in this locality. See table 5. 
Table 5. Location coefficient (CL) by sectors of the Brazilian regions for the years 2008 and 2017

\begin{tabular}{llll}
\hline Activity & 2008 & 2017 & VARIAÇÃO \% \\
\hline Biodiesel & 0.3073 & 0.2926 & $-4.78 \%$ \\
\hline Trade & 0.1782 & 0.1908 & $7.07 \%$ \\
\hline Industry & 0.0875 & 0.0821 & $-6.17 \%$ \\
\hline Warehousing Service & 0.1388 & 0.1283 & $-7.56 \%$ \\
\hline Agriculture and Livestock & 0.3836 & 0.2506 & $-34.67 \%$
\end{tabular}

Source: Prepared by the author based on data from the National Petroleum Agency - ANP (2018); Brazilian Institute of Geography and Statistics - IBGE (2018)

As shown, it can be seen when the CL in the biodiesel sector is 0.3073 in 2008 and 0.2926 in 2017 means that "the sector is distributed regionally in a similar way to all sectors analyzed as: trade, industry, storage and agricultural production (ALVES, 2014) Therefore, the biodiesel sector in 2008 and 2017 in relation to the other economic sectors is more distributed, as it is close to zero.

This distribution is explained by the fact that, in the percentage variation, the concentration capacity in production, which was low, decreased between 2008 and 2017 to $-4.78 \%$, as shown in Table 5 .

Table 6. Localization coefficient by sectors of the northern states in 2008 and 2017

\begin{tabular}{llll}
\hline Activity & 2008 & 2017 & VARIAÇÃO\% \\
\hline Biodiesel & 0.237 & 0.8158 & $244.22 \%$ \\
\hline Trade & 0.7344 & 0.688 & $-6.32 \%$ \\
\hline Industry & 0.4184 & 0.3425 & $-18.14 \%$ \\
\hline Warehousing Service & 0.1501 & 0.2079 & $38.51 \%$ \\
\hline Agriculture and Livestock & 0.8035 & 0.5595 & $-30.37 \%$ \\
\hline
\end{tabular}

Source: Prepared by the author based on data from the National Petroleum Agency - ANP (2018); Brazilian Institute of Geography and Statistics - IBGE (2018)

Regarding the states of the northern region of Brazil, it can be seen in Table 6 that the production of the biodiesel sector in 2008 was not concentrated, but in 2017 began to concentrate its productivity.

This sector concentration, between 2008 and 2017, grew 244.22\%, thus revealing that there has been little participation of the Northern States since the CL was 0.8158 in 2017, that is, the sector analyzed has a different economic distribution because CL presented approximations 1.

\section{Conclusion}

Finally, the regional analysis of biodiesel production capacity between 2008 and 2017 in the state of Tocantins, based on the location quotient and the location coefficient, is completed, but some points are highlighted in this study.

Firstly, although biodiesel production capacity in northern Brazil is very small compared to other regions of the country, it can be noted that production is very relevant for the regional and local economy in this bias, it is understood that there is There is a need for the State to seek from investors ways to strengthen and expand the biodiesel sector in Tocantins, as the study showed that the sector is fundamental to economic growth, as increased production will reflect growth in region's gross domestic product (GDP) and, moreover, can provide regional development, as such structuring can generate employment and income in the state to improve the well-being of those living in the region.

Second, it is believed that the biodiesel activity in Tocantins slowed down in 2017 due to the economic crisis facing Brazil, which may have negatively impacted companies, especially those in the Tocantins-based sector.

Among several arguments about the impacts of biodiesel, it is argued that part of the Tocantins and northern Brazil's 
regional economy was affected because the sector in 2017 had a drop in production which, consequently, may have reduced exports and thus harmed exports local economic growth.

Finally, the hypothesis that, referring to production capacity, the Tocantins biodiesel sector lost its potential in relation to the other economic sectors of the state between 2008 and 2017 is confirmed.

\section{References}

Adusumilli, N., \& Leidner, A. (2014). The U.S. Biofuel Policy: Review of Economic and Environmental Implications. American Journal of Environmental Protection, 2(4), 64-70.

Agência Nacional de Petróleo (ANP). (2018). Anuário Estatístico Brasileiro do Petróleo, Gás Natural e Biocombustiveis 2018. Retrieved April 13, 2019, from http://www.anp.gov.br/publicacoes/anuario-estatistico/anuario-estatistico-2018

Alves, L. R. (2012). Indicadores de localização, especialização e estruturação regional. In C. A. Piacenti, \& J. Ferrera de Lima (Eds.), Análise regional: metodologias e indicadores. Curitiba: Camões.

Azevedo, A. N. G. de., \& Lima, B. G. de A. (2016). Biocombustíveis: desenvolvimento e inserção internacional. Artigo. Revista Direito Ambiental e Sociedade, 6(1), 77-100. Retrieved April 18, 2019, from http://www.ucs.br/etc/revistas/index.php/direitoambiental/article/view/2693

Benko, G. (1999). Economia, espaço e globalização na aurora do século XXI. São Paulo: Huctec.

Brasil, G. do. (2019). Território nacional tem cerca de 8, 5 milhões de quilômetros quadrados. Retrieved April 25, 2019, from http://www.brasil.gov.br/governo/2009/11/territorio

Brasil, L. N., \& Dezembro, de. (2017). Dispõe sobre a Política Nacional de Biocombustíveis (RenovaBio) e dá outras providências.

Brasil, L. N., \& Agosto, de. (1997). Dispõe sobre a política energética nacional, as atividades relativas ao monopólio do petróleo, institui o Conselho Nacional de Política Energética e a Agência Nacional do Petróleo e dá outras providências.

Buarque, S. C. (1999). Metodologia de planejamento do desenvolvimento local e municipal sustentável. Brasília: Instituto Interamericano de Cooperação para Agricultura.

Câmara, D. D., \& Projeto, de L. N. (2017). Dispõe sobre a Política Nacional de Biocombustíveis - RenovaBio e dá $\begin{array}{lllll}\text { outras } & \text { providências. } & \text { Retrieved } & \text { June } & \text { 14, 2019, }\end{array}$ https://www.camara.leg.br/proposicoesWeb/fichadetramitacao?idProposicao=2162285

Farina, E., \& Rodrigues, L. (2018). A política nacional de biocombustíveis e os ganhos de eficiência no setor produtivo. Caderno opinião. Fundação Getúlio Vargas (FGV). Retrieved April 14, 2019, from https://bibliotecadigital.fgv.br/dspace/bitstream/handle/10438/22059/Coluna\%20Opiniao\%20Marco\%20-\%20Bi ocombustiveis $\% 20-\% 20$ Elizabeth $\% 20 \mathrm{e} \% 20$ Luciano.pdf? sequence $=1 \&$ isAllowed=y

Instituto Brasileiro De Geografia E Estatistica (IBGE). (2019). Tocantins. Retrieved April 25, 2019, from https://cidades.ibge.gov.br/brasil/to/panorama

Instituto Brasileiro De Geografia E Estatístisca (IBGE). (2019). Produto Interno Bruto dos Municípios. Retrieved April 12, 2019, from https://sidra.ibge.gov.br/tabela/278

Leite, R. C. De C., \& Leal, M. R. L. V. (2017). O biocombustível no Brasil, Artigo. Revista: Novos Estudos 78 Julho.

North, D. (1977). Teoria da localização e crescimento econômico regional. In J. Schwartzmann (Ed.), Economia regional e urbana: textos escolhidos (pp. 333-343). Belo Horizonte: UFMG.

North, D. C. (1955). Location theory and regional economic growth. Journal of Political Economu, 63(6).

Oliveira, N. M., \& Piffer, M. (2018). Determinantes do Perfil Locacional das atividades produtivas no Estado do Tocantins. Boletim de Geografia (UEM), 36, 92-111.

Paiva, C. A. N. (2004, June). Demanda Efetiva, Exportações e Desenvolvimento Regional (ou: Smith, Kalecki e North e os fundamentos de uma teoria do desenvolvimento de regiões periféricas em transição para o capitalismo). IX Econtro Nacional de Economia Politica. Anais, Sociedade Brasileira de Economia Política, Uberlândia $(M G)$.

Piffer, M. (2009). A teoria da base econômica e o desenvolvimento regional do Estado do Paraná no Final do Século XX. 167f. Tese. PhD Dissertation, Universidade de Santa Cruz do Sul, UNISC, Santa Cruz do Sul. Retrieved 
January

2 ,

2020 ,

from

http://files.luciralves.com/200000046-4cfe94df86/A\%20teoria\%20da\%20base\%20econ\%C3\%B4mica\%20e\%2 0o\%20desenvolvimento\%20regional $\% 20$ do $\% 20$ Estado $\% 20$ do $\% 20$ Paran $\%$ C3\%A $1 \% 20$ no $\% 20$ final $\% 20$ do $\% 20$ s $\%$ C3\%A9culo\%20XX.pdf

Rauch, A., \& Thöne, M. (2012, January). The global subsidies initiative biofuels - at what cost? Mandating ethanol and biodiesel consumption in Germany. For the Global Subsidies Initiative (GSI) of the International Institute for Sustainable Development (IISD) Geneva, Switzerland.

Rei, F. C. F., Gonçalves, A. F., \& Souza, L. P. de. (2017). Acordo de Paris: reflexões e desafios para o regime internacional de mudanças climáticas. Artigo. Veredas do Direito, Belo Horizonte, 14(29), 81-99.

Richardson, H. W. (1975). Economia regional: teoria da localização, estrutura urbana e crescimento regional. Rio de Janeiro: Zahar.

Rua, M. G. (1998). Análise de políticas públicas: conceitos básicos. In M. G. RUA, \& M. I. V. Carvalho (Eds.), $O$ estudo da política: tópicos selecionados. Brasília: Paralelo 15. Coleção Relações Internacionais e Política.

Schwartzman, J. (1975). A teoria da base de exportação e o desenvolvimento regional. In P. R. Haddad (Ed.), Desequilíbrios regionais e descentralização industrial. Rio de Janeiro: IPEA/INPES.

Vergara, S. C. (2016). Projetos e relatórios de pesquisa em administração (16th ed.). São Paulo: Atlas. 